\title{
Stanislaw Obirek SJ, Wizja państwa w nauczaniu jezuitów polskich w latach 1564-1668, Kraków 1995, ss. 71
}

Jak pisze Autor na początku omawianej pracy, ,jezuici stanowili zawsze przedmiot licznych publikacji, ale szczególnie $w$ ostatnim okresie literatura na ich temat wzbogaciła się o wiele cennych rozpraw naukowych" 1 . Wśród nich znalazło się kilka prac autorstwa Stanisława Obirka, jezuity z Krakowa.

Omawiana praca składa się z czterech rozdziałów. Pierwszy opisuje strukturę zakonu i formy rządzenia, drugi normy ogólne, trzeci stosunek jezuitów do kontrreformacji. Wreszcie czwarty, stanowiący zasadniczy trzon pracy - poświęcony jest jezuickiej wizji państwa przedstawianej w szkołach.

Autor skoncentrował się na wykładach jezuickich, traktatach, teatrze szkolnym i kaznodziejstwie. Wykorzystał treści zawarte w wykładach filozofii, m.in. prowadzonych przez Leonarda Krakera, Jana Kleina, Stanisława Radzimskiego, Andrzeja Nowaka i Wojciecha
Sokolowskiego czy Jana Chądzyńskiego. Wskazuja one na to, iż jezuici interesowali się aktualnymi problemami polskimi i litewskimi. W szkołach ówczesnych doniosłą rolę odgrywał teatr, szczególnie w wychowaniu politycznym młodzieży. Poprzez szkolne przedstawienia starano się wyksztalcić w uczniach cnoty obywatelskie. Podobnie wykorzystywano kazania, w których często pojawiały się treści polityczne - Piotr Skarga, Jakub Wujek, Marcin Laterna, Stanisław Grodzicki $\mathrm{i}$ in. Tak więc, mimo iż oficjalnie jezuitów obowiązywał zakaz publikowania poglądów o charakterze politycznym, spotykamy je w ich twórczości i działalności.

Praca S. Obirka stanowi kolejny krok do badań nad dziejami jezuitów polskich.

(D.Z.-S.)

${ }^{1}$ S. Obirek, Wizja państwa w nauczaniu jezuitów polskich w latach 1564-1668, Kraków 1995, s. 5.

\section{Jezuicka ars educandi. Prace ofiarowane Księdzu Profesorowi Ludwikowi Piechnikowi SJ, Kraków 1995, ss. 288}

W poprzednim numerze Biuletynu przedstawiliśmy sylwetke Księdza Profesora Ludwika Piechnika. W zwiazku z omawianym jubileuszem 75 rocznicy urodzin ukazała się książka ofiarowana Profesorowi.

Tom ten rozpoczyna, jak zwykle przy takich okazjach, "portret nie tylko naukowy” Jubilata oraz zestawienie prac Profesora.

Następnie w kolejności alfabetycznej zamieszczono kilkanaście rozpraw różnych autorów.

Kongregacje Generalne Towarzystwa omawia P.J. Badura SJ. Rozmaitym aspektom dziejów szkolnictwa jezuickiego poświęconych jest kilka szkiców. I tak dzieje szkolnictwa jezuickiego w świetle prac L. Piechnika prezen- tuje F. Paluszkiewicz SJ, jezuickie budynki szkolne J. Paszenda SJ, nauczanie logiki matematycznej w Wilnie R. Pleckaitis, a tradycje i nowatorstwo w wykładach retoryki w kolegiach jezuickich E. Ulcinaite, wileńskie Collegium Nobilium jezuickie $\mathbf{i}$ jego rolę w kształtowaniu elit w Polsce K. Puchowski, niemieckie szkoły jezuickie i ich polskich uczniów D. Żołądż, przejawy baroku w teatrze jezuickim XVIII wieku I. Kadulska. Twórczość pisarzy jezuickich analizują - Piotra Skargi w kontekście jego polemik z arianinem Hieronimem Moskorzowskim - P. Wilczek, natomiast filozofię Stefana Sczanieckiego - R. Darowski SJ, a spojrzenie na państwo $\mathrm{i}$ społeczeństwo Tomasza 
Młodzianowskiego - K. Przyboś. Antymakiawelizm jezuicki omawia S. Obirek SJ.

Ponadto XIX-wiecznym dziejom edukacji poświęcone sq̨ studia J. Dybca o roli studiów zagranicznych w kształtowaniu inteligencji gali- cyjskiej i L. Grzebienia SJ poświęcone konwiktowi szlacheckiemu we Lwowie w latach 1842 - 1848.

(D.Z.-S.)

\section{W kręgu akademickiego Zamościa. Materialy z międzynarodowej konferencji, red. H. Gmiterek, Lublin 1996, ss. 344}

Omawiana praca jest rezultatem konferencji nt. „Akademia Zamojska na tle praktyki edukacyjnej w Europie Srodkowo-Wschodniej (koniec XVI-koniec XVIII wieku)", która odbyła się w dniach 11 - 13 maja 1995 roku w Lublinie i Zamościu.

Tom rozpoczynaja rozprawy dotyczące obcych środowisk szkolnych - Akademia Strasburska i jej rektor Jan Sturm (Andre Seguenny), praskie środowisko akademickie (Jaroslav Panek), szkolnictwo na Morawach, ze szczególnym uwzględnieniem kolegium jezuickiego w Ołomuńcu (Jindrich Schulz i Jana Buresova).

Sylwetce fundatora poświęcili swe studia Stanisław Grzybowski (o Zamoyskim jako wychowawcy młodzieży szlacheckiej) oraz Marek Kuryłowicz (prawo rzymskie w studiach i koncepcjach akademickich Zamoyskiego). Rolę jego wnuka Jana Sobiepana Zamoyskiego i jego stosunek do Akademii omawia Eugeniusz Janas.

Profesorów Akademii Zamoyskiej dotyczą następujące rozprawy: Mariana Chachaja (o wykształceniu profesorów Akademii Zamojskiej), Mariana Lecha Klementowskiego (o ich udziale w sądownictwie Zamościa), promocje doktorskie w Akademii przedstawia Henryk Gmiterek; sylwetki profesorów omawiają: Halina Wiśniewska (Jana Ursinusa i Stanisława Niewieskiego), Bogdan Rok (Stanisława Duńczewskiego), Władysław Froch (Bazylego Rudomicza), Edward A. Mierzwa (Williama Bruce).
Funkcjonowaniu Akademii w środowisku miasta i Rzeczypospolitej poświęcony jest następny blok studiów. Roman Szust omawia kontakty lwowian z Akademią w XVII i XVIII wieku, Marian Pawlak kontakty szkolne północnych ziem Rzeczypospolitej z Zamościem, Witold Kłaczewski i Waclaw Urban szlachtę lubelską, jej stosunki z Akademią $i$ udział $w$ kształtowaniu elit intelektualnych Lubelszczyzny, kontakty Rusi Czerwonej z Zamościem omawia Wiesław Bondyra.

Agnieszka Sidorowska przedstawiła okoliczności likwidacji Akademii Zamojskiej w 1784 roku, a Bogdan Szyszka omówil szkoły będące kontynuatorkami tradycji Akademii.

Tom kończy studium Zdzisława Pietrzyka dotyczące źródeł do dziejów peregrynacji studenckich w XVI i XVII wieku na przykładzie Strasburga.

Tom ten, jak ma nadzieję jego redaktor Henryk Gmiterek, ma stać się ,istotnym przyczynkiem do opracowania nowej, krytycznej monografii Akademii Zamojskiej, lokującej ja w całokształcie ówczesnych uwarunkowań kulturowych, spolecznych, ekonomicznych i politycznych" ${ }^{1}$.

(D.Z.-S.)

1 H. Gmiterek, Przedmowa. w: Wkregu akademickiego Zamoscia. Materiały z międzynarodowej konferencji, red. H. Gmiterek, Lublin 1996, s. 6. 